\title{
The Devastating Local Currency and the Unofficial Dollarization in Somalia
}

Ahmed Nuh YUSUF, Abdurrahman OKUR ${ }^{1}$

Article Info

Article History:

Date Submitted: 25.06.2019

Date Accepted: 25.08 .2019

Jel Classification

F31, E42, E58

Keywords:

Dollarization

Exchange rate volatility,

Currency devaluation,

Somali Shilling

\begin{abstract}
Currency devaluation and prevalent unofficial dollarization in Somalia inspired the volatility of exchange rate. U.S dollar has become a good choice to store the value to prevent the volatility of the Somali Shilling and its frequent devaluation. Almost all price tags of products and services are charged in dollar form including the salaries of public and private employees, taxes collected by the central government and FMS, rentals and school fees. Commercial banks deposit, lend clients and charge bank fees solely in USD. The only remaining one denominator of the Somali Shilling in the markets is heavy to carry, old and damaged to be in circulation and susceptible to be faked. The study employed time series analysis to investigate the volatility of the exchange rate and its relationship with the dollarization using daily nominal exchange rate data for the study period 20092018. Empirical results indicate that the exchange rate regime has no major consequence in promoting dollarization. Introducing new domestic currency is deemed very necessary, but considering the challenges faced by the weak central authority, such initiative is hard to be achieved in the near future.
\end{abstract}

\section{Introduction}

Dollarization is the use of other people's money in another people's economy, officially or unofficially. To dollarize the economy mainly involves dollarizing deposits and loans of the banks, exchanging in dollars and tagging prices of goods and services in dollar. Dollarization is usually common at some of the countries with deficiency to engage in an effective macroeconomic system. Dollarization undermines the monetary sovereignty and results loss of autonomous monetary policy (Musoke, 2017: 2).

Historically, Somalia was a pastoral economy based on barter trade between small agriculturalists and nomadic herdsmen (Chossudovsky, 2011). Recent years of effective central authority absence, the main contributors to Gross Domestic Product (GDP) were agriculture,

\footnotetext{
${ }^{1}$ Dr. Öğretim Üyesi, Hacı Bayram Veli Üniversitesi, Bankacılık ve Sigortacılık Yüksekokulu.
} 
livestock, financial and telecommunications services (African Development Bank, 2019: 175). Dollarization is adopted in Somalia right after the collapse of the Central Bank of Somalia (CBS) and all other public institutions in 1991. Resulting from the outbreak of the civil war and prolonged political unrest that's ongoing nearly three decades.

Since then, the circulation of the banknotes throughout the country was self-governing. The latest officially printed banknote that was issued and released by CBS into the Somali economy was before 1991. The collapse of CBS left no remedy to meet the cash need of the Somali economy, replace the amount of old, damaged or mutilated banknotes in the economy and put clean banknotes into circulation. However, banknote printing was done by either private business owners or Federal Member States (FMS) in different periods of time -by printing domestically within the country or sometimes importing Somali Shilling from abroad; and neither was authorized to do the job of a central bank but eventually benefited from the lack of central authority with the monopoly power to rule over.

The aftermath of the latest effective and only modern Somali central authority didn't go well for the people of Somalia; it was only functioning thirty years after its independence from Italy and Britain in 1960 but even in that short period, tested both market and socialist economic systems as it came into an existence during last thirty years of the rival in the Cold War.

United States dollar remains the most stable and reliable currency used as a medium of exchange throughout the country either in physical or in value for more than two to three decades (Nor, 2012: 596). The unofficial dollarization is adopted gradually by the people voluntarily in order to overcome the stress of the consistent local currency devaluation, the absence of the central bank that has the ability to decide the amount of banknotes in circulation and the floating exchange rate regime which is highly fragile and susceptible to financial stability risks. The dollarization in the country is devastating the poorer households who do not earn income in hard currency. Most of them hardly gain income; they run very small businesses and sell their products and services in local currency. But, suffer buying many things back in U.S dollars. At the time of excessive depreciation which is the case of the Somali Shilling since 1990 's, there was no CBS exchange rate policy to reduce the effect.

The current Somali Shilling which suffers from being only one denominator - thousand shilling due to severe devaluation is heavy to carry in the pockets, old and damaged to be in circulation, 
susceptible to be faked. Thus, the need to introduce new domestic currency is deemed very necessary, but considering the challenges faced by the weak central authority, such initiative is just a dream that's hard to be achieved.

Countries should implement policies to reform when they decide to go for dollarizing their economy. As Eichengreen, (2002) argues, dollarization is not by itself leading to policy reforms. Additionally, dollarization can strengthen the banking system of a country, but must not be seen as something that cures all the problems of an economy. Close supervision, regulation, and foreign openness must also exist in there, and be enhanced by the support of dollarization (Matthews, 2006).

\section{Literature Review}

As adopted from Calvo's definition of dollarization, it is "the use of foreign currency in any of its three functions: unit of account, means of exchange and in particular, store of value" (Duffy, Nikitin \& Smith, 2006: 1). Business dictionary (2019) defines dollarization as the incident when foreign country's currency is adopted as legal tender in another country's soil resulting from the value of alternate country's currency is more reliable than the standard currency used in the home country. It was noted that dollarization may let the countries to get access into integration with international markets, possibility to get competitors from other countries and domestic investors may get availability to a range of assets. Besides, in countries with inflationary experience, people don't have enough experience with the domestic currency, thus dollarization sometimes restores local intermediation, remonetizes the economy and reverses capital flight (Baliño et al, 1999).

Dollarization both official and unofficial is common in many countries around the world specifically in Asia, Africa and South America. It has been adopted by many countries in Latin America - Peru, Argentina and much of Central American Countries. Argentina adopted currency board linked to the U.S dollar in 1991. Currency boards that lock dollar or euro to their local currencies also exist in Bulgaria, Lithuania, Estonia and Hong Kong. Ecuador adopted full dollarization when El Salvador declared its commitment to follow the same path in 2000 (Alberto, Alesina \& Barro, 2001).

It is necessary to identify the different forms of dollarization in contrast to other studies available at the literature limiting dollarization into foreign currency deposit to the broad money 
(Mengesha \& Holmes, 2015). For example, commercial banks in Tanzania have the power to let their account holders to open foreign currency deposit accounts, giving them the freedom to pay and save in foreign currency. Due to the instability of the domestic shilling compared to the foreign currencies, clients hold bank accounts in foreign currencies preferably U.S dollar (Musoke, 2017: 2). Volatility of the exchange rate and constant inflation are some of the consequences that cause to rely on hard currency or dollarization (Mengesha \& Holmes, 2015).

The emergence of dollarization is not only the consequence of economic stress. Therefore, some of the main factors that cause dollarization are considered to be the recent regional economic integrations and the growing volume of world commerce and trade. Although, joining a currency union diminishes the political union as that country can easily be dominated by the other countries in its region (Alesina, Alberto \& Barro, 2001). The losses of the devastating government of Cambodia in fiscal, foreign trade and monetary policies seemed to outweigh the benefits it obtained from stabilizing price levels and reduction of national default risk. In addition, considering the dollarization effect on income distribution, there is no doubt to conclude that the Cambodian government should work on to review its dollarization as soon as possible (Kang, 2005).

A study on the implications of dollarization in El Salvador indicates that the costs associated with dollarization outweigh its benefits. The study also points out that the decision to dollarize is often associated with broad economic crises that demand a drastic economic readjustment, inflation control and the need to control the exchange rates (Towers \& Borzutzky, 2004). Both Ordinary Least Square (OLS) and Bayesian model averaging estimates presented in the study on the effect of dollarization on financial crises of 2007-09 in emerging economies suggest that unofficial dollarization/euroization was significant contributor to the severity of the crisis (Chiţu, 2012: 5).

Unofficial dollarization is the result that arises from the competition of domestic currency and the U.S dollars as a medium of exchange (Duffy, Nikitin \& Smith, 2006: 1). The same way Somali Shilling is defeated by the U.S dollar. An empirical study on official dollarization regime in Montenegro based on costs and benefits after the dollarization, has outlined that dollarization does not guarantee firm economic policy (Lakić et al, 2016: 52). The study found that costs exceed benefits as its economy is deteriorating. Montenegro is now having less power to intervene and adjust its external imbalances such as capital flow. Montenegro is part of the currency union in Europe but it is not an EU member, thus adopted other people's money in 
their economy, except that Montenegro is candidate to join. The motive of the academic debaters who investigated negative implications of dollarization was that dollarization restricts the possibility to intervene the monetary policy, stabilize the output, implement fiscal regulations and reduce inflation rates and transaction costs. It also limits the ability to mediate foreign exchange risk and develop financial and banking system ((Lakić et al, 2016: 61). Even though, a study that examined inflation and the demand for foreign currency or dollars as a store of value and capital accumulation concludes that the only way to avoid dollarization is to decrease the inflation under the threshold level (Duffy, Nikitin \& Smith, 2006: 19).

Bogetic (2000) investigated on the experience of Panama under dollarization has reached the conclusion that the nation had benefited gains from the system it adopted. Panama survived from banking crises that overwhelmed other Latin American nations. The advantages of dollarization substantially outweigh the costs, due to technological innovations that have undermined the demand of money therefore, reduced the losses from seigniorage. Yet, dollarization may have positive economic effects in case there is an understanding of the basic conditions of the country that is willing to adopt dollarization (Calvo, 2002). In addition, dollarization may contribute in the creation of a more competitive domestic economy through reducing the risks of devaluation (Calvo, 2002).

As the case of Montenegro, dollarization resulted positive effects on reducing inflation, reduced interest rates at first years; it helped banking system to develop but also shown deterioration in fiscal indicators (Lakić et al, 2016: 61). Not only that but also it has been observed that exclusively dollarization cannot be considered the only factor that generated these positive effects in Montenegro.

\section{Methodology and Data}

The paper adopted several approaches to measure and estimate the volatility of the nominal exchange rate using daily data from January 1, 2009 to December 31, 2018 consisting 3110 observations. The approaches employed to measure the extent of volatility are simple historical volatility or moving average (MA), exponentially weighted moving average (EWMA) and generalized autoregressive conditional heteroscedasticity $\operatorname{GARCH}(1,1)$ models to find the estimate of periodic standard deviation of the ten year period. After the GARCH $(1,1)$, other models of Autoregressive Conditional Heteroskedasticity (ARCH) family were also applied to the study in order to justify the use of the models in the paper. Models applied are Threshold- 
ARCH (TARCH or GJR-GARCH) which expands GARCH $(1,1)$, exponential generalized autoregressive conditional heteroscedastic (E-GARCH) and ARCH to find out the best model that fits the most in the study using Akaike Information Criterion (AIC) and Schwarz Information Criterion (SIC). The lower AIC and SIC, the better the model for our study with the sample size of 3110 days. The data is obtained from the Central Bank of Somalia (CBS).

Robert Engle (1982: 989) introduced ARCH models and it is generalized as GARCH (Generalized ARCH) by Bollerslev (1986: 311). The models are useful in diverse branches of econometrics, particularly in financial time series analysis.

Assuming that, periods of high volatility is followed by periods of high volatility whereas periods of low volatility is followed by periods of low volatility for prolonged period (see figure 3). Residuals show ARCH effect. Therefore, ARCH family models are highly recommended and it is enough reason to employ in the study.

Moving average (MA) has the weakness that it is assigning all the returns to the same weight. However, EWMA is the next level of sophistication to estimate the volatility. It has the feature to assign greater weights to more recent returns and lesser weights to returns that are more distant in the past to overcome the key weakness of historical standard deviation which is implicitly equally weighted or unweighted. Despite that EWMA shares much in common with the historical standard deviation; it is not common measure of volatility in academic papers. Therefore, GARCH $(1,1)$ is the most common approach to estimate volatility and generalizes the EWMA while it also assigns the returns to exponentially declining weight but in addition, it models the long-run variance.

The historical standard deviation or MA is expressed as follows:

$$
\sigma_{\mathrm{n}}^{2}=\frac{1}{m} \sum_{i=1}^{m} u_{\mathrm{n}-1}^{2}
$$

Where $\mathrm{m}=$ number of days measured, $\mathrm{n}=$ day $i$ and $\mathrm{u}=$ difference of return from the average return.

The EWMA is generalizing the MA specification by weighting it with $\lambda$ and it is expressed as follows: 


$$
\sigma_{n}^{2}=(1-\lambda) u_{n-1}^{2}+\lambda \sigma_{n-1}^{2}
$$

The GARCH $(1,1)$ model specification can be expressed as follows:

$$
\sigma_{n}^{2}=\omega+\alpha u_{n-1}^{2}+\beta \sigma_{n-1}^{2}
$$

Where $\omega=\gamma \sigma^{2}(\mathrm{LR})$ and it gives weight to long-run or unconditional variance and it employs three parameters which are $\omega, \alpha$ and $\gamma$ equaling 1.0.

\section{Measuring the Unofficial Dollarization in Somalia}

At the time countries adopt full dollarization, the currency in circulation, holdings of deposit by people in both domestic and offshore banks is usually expected to be the foreign currency adopted by the relevant country as the only legal tender. Complexity to measure dollarization comes in the case of unofficial dollarization. The unofficial dollarization is the result from the lack of confidence in home currency; its consequence comes from the fact that the government doesn't encourage policies that improve domestic currency stability (Honig, 2009). However, measuring the extent of dollarization is hard, but International Monetary Fund (IMF) and other interested entities consider mainly a standard measure to be based on foreign currency deposits to broad money in the economy also referred to as Dollarization Index (DI) (Musoke, 2017: 4). Identifying the extent of unofficial dollarization in a country was never easy, as dollarization has different forms that reflect the economy of a nation e.g. dollarization in the black market. Thus, other standard measures are also applicable (Mengesha \& Holmes, 2015). As the case of Somalia, it is even harder to measure the degree of the unofficial dollarization using DI due to the preference of many people to not hold their hard currency at banks resulting from the economic system which is too informal, the low literacy rate or the trauma of the outbreak of the civil war that caused all banks to collapse in 1991.

Unofficial dollarization prevailed in Somalia extensively because of its convenience to carry and as a good choice to store the value thus to prevent the volatility of the Somali Shilling and its frequent devaluation. Hundred percent of bank deposits are based on U.S dollar. Apart from that, almost all price tags of most products and services are charged in dollar form. This includes the salaries of public and private employees, taxes collected by the central government and 
FMS, rentals and school fees. This system in Somalia can be named as quasi official dollarization.

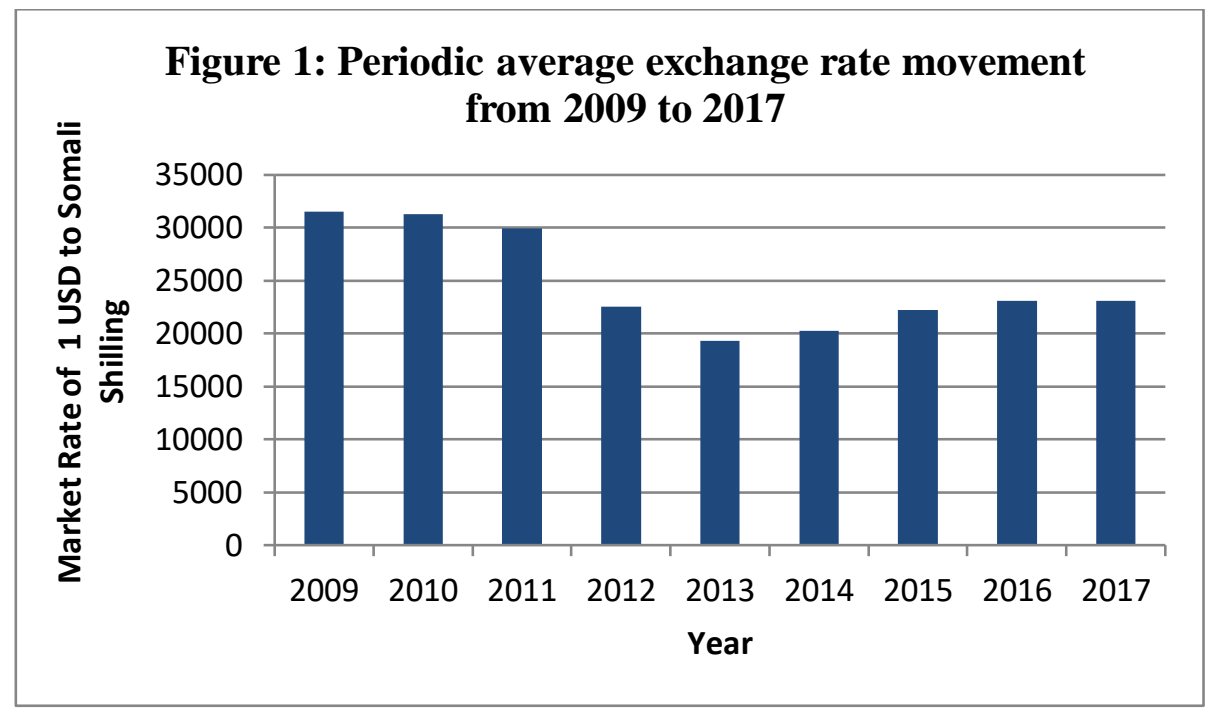

Source: Authors' calculation based on data of OICStat

\section{Sources of the hard currency}

The massive increase of U.S currency holdings in Somalia is triggered by the money transfer from Somali diaspora "Hawalla" or "worker's remittance", the absence of the control of the central bank and other monitoring financial authorities, the increase in exports and imports, the lack of confidence in Somali currency, the simplicity in which the Somali Shilling can be printed and many other factors (Musse \& Echchabi, 2017: 19). Nor (2012: 596) thinks that the root cause for the dollarization in Somalia is the price fluctuation, the continuous devaluation of Somali shilling and the economic stress which grants relieve to the ordinary citizens to employ U.S dollars in Somali markets in contrast to the other parts of the world in which U.S dollar is depreciating.

In addition to the worker's remittance, according to the Somalia's Ministry of Finance, foreign grants have amounted total of 363.1 Million Dollars in the period of 2014-2018 towards budget support to the government revenue. These grants were received from the strategic partners of FGS - World Bank, Saudi Arabia, Qatar, Arab League, Turkey, U.A.E., Norway, European Union, African Development Bank, United Nations and others to cover government expenditures and implementation of development projects (see figure 2). 
The World Bank is the biggest contributor to foreign grants. It donated approximate of $47.29 \%$ of total grants in the period of 2014-2018. Other major source of the dollar to the country is the export of the livestock and other agricultural products.

Figure 2: Foreign Grant Revenues of Somali Government in USD 2014-2018

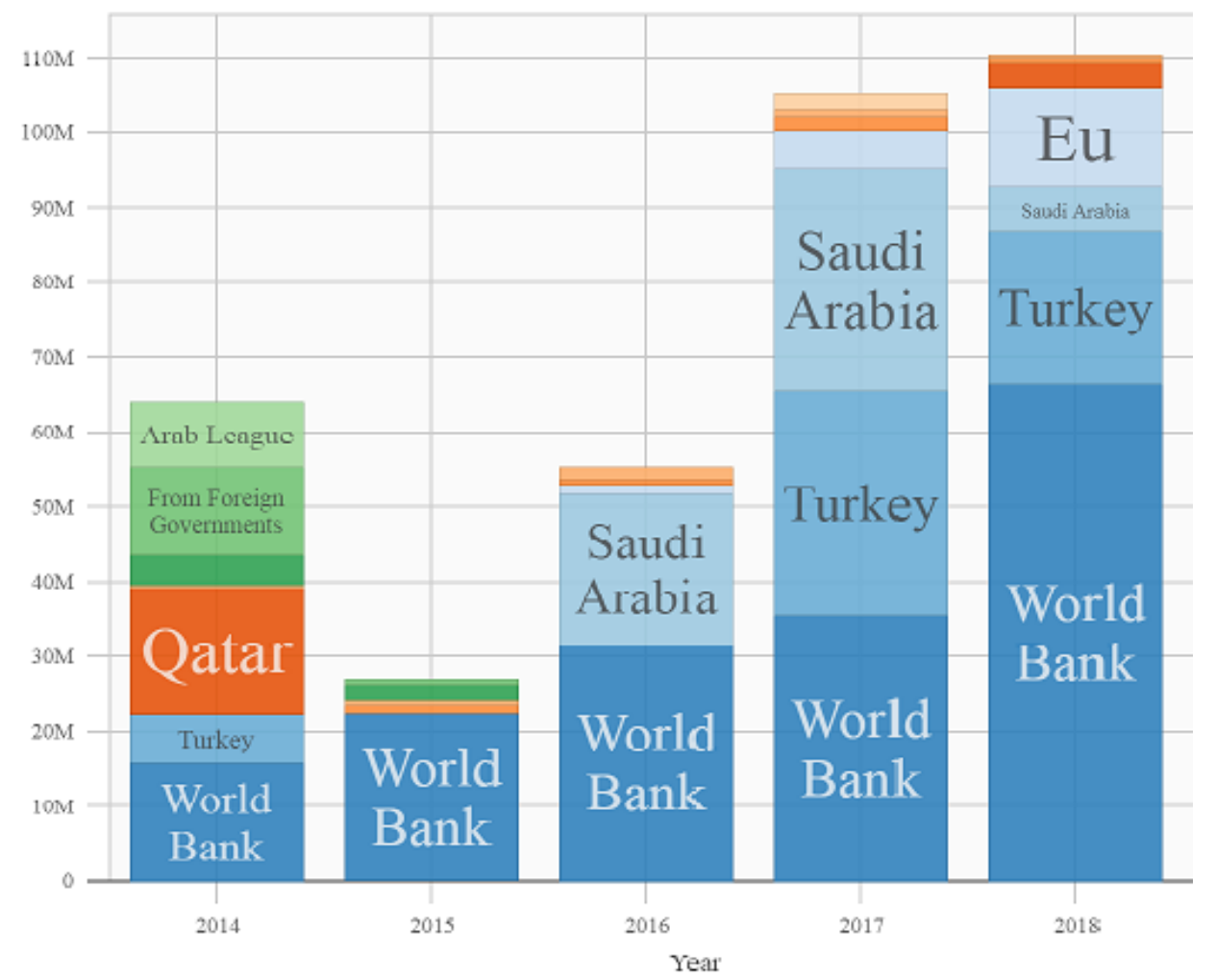

Source: Ministry of Finance, Mogadishu, Somalia

The floating exchange rate regime is controlled by private businessmen on daily basis, the rate is determined most of the time by the supply of the dollars in the market and the rate of the dollar usually goes up at the end of every month or the start of a new month, indicating the flow of hard currency from abroad. The country's dependency on import of almost every product including food and the import of the expensive "Khat" - (a legal drug chewed by many Somalis extensively on daily basis) which is a cash crop for the neighboring countries of Kenya and Ethiopia do contribute the vulnerability of Somali shilling and it should not be overlooked.

Somaliland which is seeking independence from Somalia regulates its Somaliland Shilling instead of the Somali Shilling, but the same degree of other parts of Somalia, U.S dollar is the dominant currency. However, all major transactions in Somaliland are undertaken in U.S 
dollars (Koshin, 2017: 85). Dollarization can hit overall economy of Somalia. Therefore, the system must be reviewed in order to avoid the shocks that originate from the value of the dollar (Musse \& Echchabi, 2017: 21).

\section{Do commercial banks contribute the unofficial dollarization?}

The return of banking industry back to Somalia came to an existence after its disappearance of nearly two decades excluding financial institutions that were implementing basic bank job of opening current accounts but mainly focused on remittance, transferring cash from/to abroad and domestically. Later, some of giant telecommunication companies and remittance firms started subsidiaries; most of the commercial banks in operation are owned by them. Currently, there is no conventional bank in Somalia whilst the new banking sector in the country prefers Islamic finance in the treatment of risk and how risk is shared. All commercial banks that operate in the country generate their revenues through an Interest-free system. The banks mainly earn revenues from "Murabaha" or sometimes called cost-plus financing which is a scheme that allows for banks to lend customers. This system which is not an interest-bearing loan is an acceptable form of credit sale under Islamic law. Murabaha is an Islamic financing system in which the supplier offers the product based on cost and profit margin of an asset. The rise of Islamic banking system in Somalia can be attributed to the sociological change of the society. The only working currency adopted by commercial banks is U.S dollar.

Recently, the banking sector is booming in Somalia, there are up to 10 banks and 12 local and international money transfer companies registered by CBS. These financial institutions face challenges of operating in a country that is difficult to carry out Automated Teller Machine (ATM) services but instead, some financial institutions have innovated a mechanism that facilitates for their customers to withdraw/deposit their money in the accounts using their mobile phones electronically, but again in U.S dollars. It is believed that mobile money has even boosted the dollarization in Somalia. Banks handle personal and corporate accounts in U.S dollars; they lend clients and charge bank fees at the same currency.

\section{Empirical Results and Interpretation}

The three most common approaches to estimating current variance or volatility that are moving average (MA), exponentially weighted moving average (EWMA) and the very popular GARCH $(1,1)$ with their different levels of sophistication are applied in the study to determine the periodic standard deviation of the daily exchange rate. 
The daily variance or $\sigma^{2}$ (MA) is $0.0212 \%$ and the daily volatility or $\sigma$ (MA) equals $1.4566 \%$ whereas using EWMA approach, the daily variance is $0.0975 \%$ and the daily volatility is $3.1219 \%$ (See table 3). EWMA is bigger than the simple historical standard deviation because the weights decline exponentially or in constant proportion at ratio of $\lambda$ which equals 0.8 , though it is hard to objectively fit the algorithms.

Table 1: Estimating Volatility in both MA and EWMA for the exchange rate between January 1, 2009, and December 31, 2018

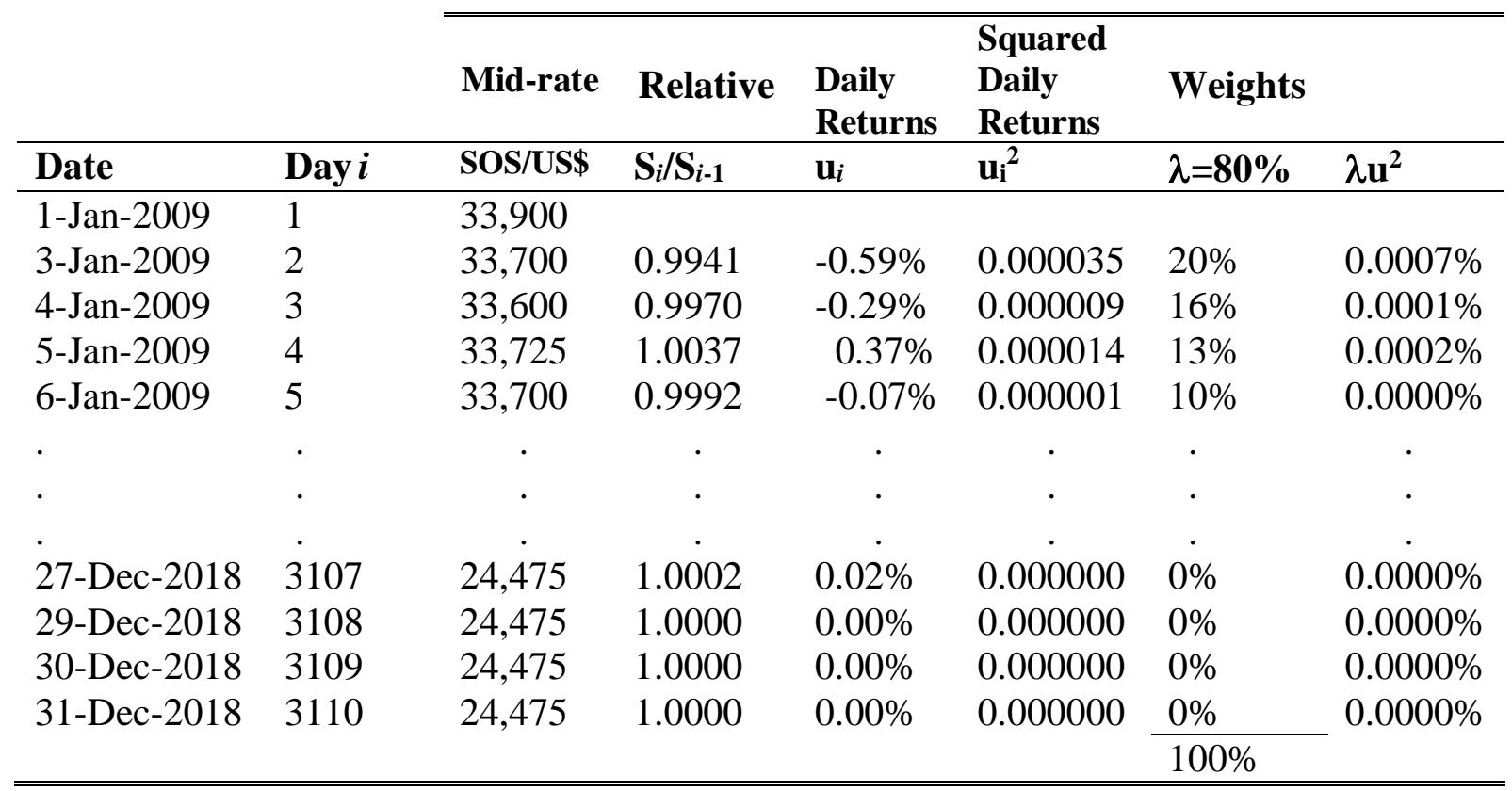

The estimation of the model selected to determine the volatility other than the MA that credits all the squared daily returns equally by overlooking the high or low periodic volatility of sometime within the period is GARCH $(1,1)$. The model is easier to fit the algorithms and it specifically parameterizes $\alpha, \beta$ and $\gamma$ weights based on historical series objectively and even useful to forecast. Adopting the long-run variance $\left(\mathrm{V}_{\mathrm{L}}\right)$ into its model or sometimes called unconditional variance, GARCH $(1,1)$ got popularity among literature to analyze volatility as part of ARCH family. The parameters of $\gamma, \alpha$ and lastly $\beta$ values are determined using Maximum Likelihood Method (MLE). 
Figure 3: Residuals of Daily Exchange Rate 2009-2017

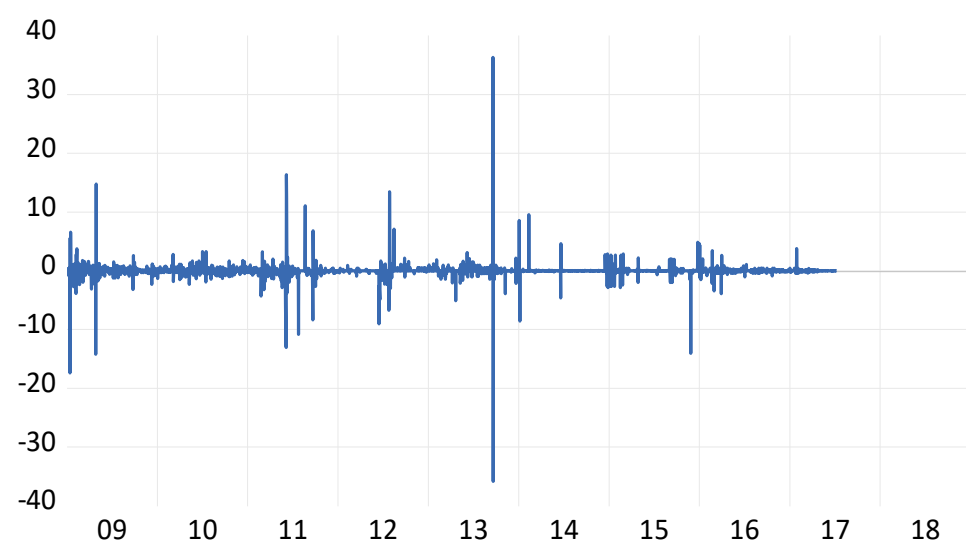

Figure 4: Daily Volatility of Exchange Rate 2009-2018

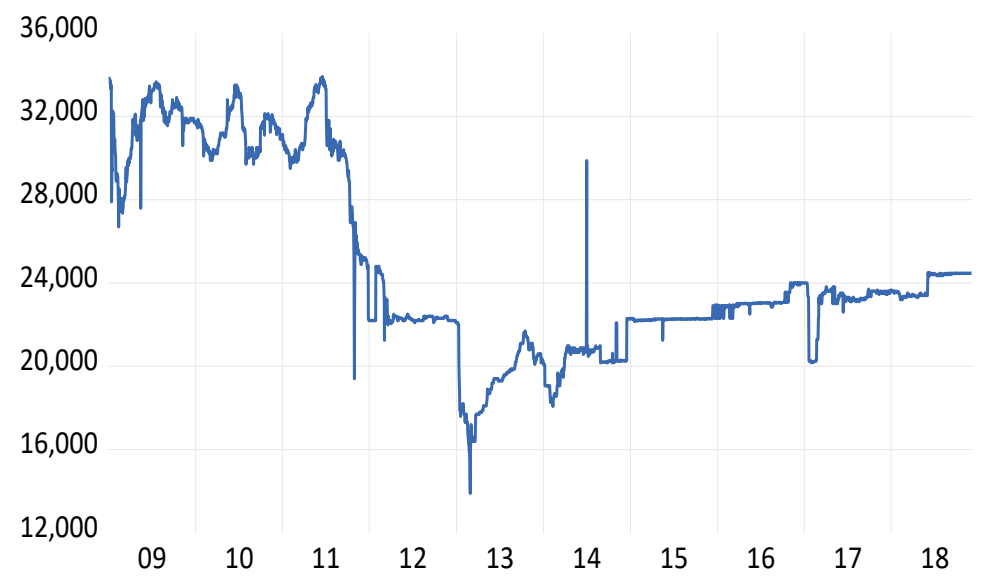

The unit root test or stationary test was conducted at intercept, the Augmented Dicky-Fuller (ADF) Test statistic and p-values show less than 5\% which mean that the exchange rate fluctuation is stationary. But, once more, in order to double check the justification, ARCH-LM test (Lagrange multiplier test) is used to test $\mathrm{ARCH}$ in the residuals and it shows p-value of 0.0000 which is less than five percent indicating the presence of ARCH effect at lag 4. The null hypothesis which is "there is no ARCH effect" is rejected and alternative hypothesis is accepted which says that there is ARCH effect. It is also confirmed the absence of serial correlation or autocorrelation in residuals from the time series analysis using Durbin Watson Test. Autocorrelation may mislead us by underestimating the standard error by showing the similarity of a time series over successive time intervals. The Durbin Watson Test result is 2.36. It is negative value but it is not showing a matter of concern so long as it is in between 1.5 to 2.5. Thus, this figure is considered relatively normal out of the range of 0 to 4 . Negative value of Durbin Watson Test indicates that if the rate of exchange fell today, there is greater likelihood 
that it will raise today. However, allowing the study to justify running ARCH family models such as ARCH, GARCH, E-GARCH and TARCH. Despite that ARCH has the lowest AIC and SIC compared to all other models of $\mathrm{ARCH}$ family mentioned above, $\operatorname{GARCH}(1,1)$ is employed in this study as it can handle most of financial problems with fewer parameters which captures facts of the past volatility patterns and also useful in place of $\mathrm{ARCH}$ process which is not so commonly used recently in academic papers (See table 2). However, GARCH $(1,1)$ is chosen as the base of this study.

E-GARCH Model which models the log variance and adopts both asymmetric and symmetric terms shows positive leverage effect $\theta$ and it is statistically significant indicating that there is no asymmetric effect (the conditional variance has no significant effect on the exchange rate volatility) which means bad news e.g. inflation \& currency devaluation do not increase volatility more than good news of the same size in the study which may also mean that there is positive correlation between the past return and future volatility of return i.e. when the exchange rate returns goes up, the volatility goes up also, when the exchange rate returns goes down, the volatility goes down.

ARCH term is 0.303379 which shows effect of volatility towards returns and GARCH volatility is 0.258945 and both are significant. The sum of the ARCH and GARCH coefficients $(\alpha+\beta)$ is $\mathbf{0 . 5 6 2 3}$ at normal distribution, indicating that volatility shocks are not very much persistent in the 10 years of the study.

The coefficient $\alpha$ indicates the reaction of volatility to the shocks or unexpected return, whereas, the coefficient $\beta$ indicates the persistence of the volatility i.e. how long the volatility would take to return back to long-run volatility.

Table 2: ARCH, GARCH $(1,1)$, E-GARCH $(1,1) \&$ TARCH results of SIC, AIC and Log Likelihood

\begin{tabular}{lllll}
\cline { 2 - 5 } & ARCH & $\begin{array}{l}\text { GARCH } \\
(1,1)\end{array}$ & $\begin{array}{l}\text { E-GARCH } \\
(1,1)\end{array}$ & TARCH \\
\cline { 2 - 5 } SIC & 2.81 & 3.11 & 2.89 & 3.10 \\
AIC & 2.79 & 3.10 & 2.87 & 3.09 \\
Log Likelihood & -4340.359 & -4815.359 & -4460.474 & -4793.873 \\
\hline \hline
\end{tabular}


Table 3. Results of daily volatility based on MA and EWMA

\begin{tabular}{lll} 
& MA & EWMA \\
\cline { 2 - 3 } Daily Variance & $0.0212 \%$ & $0.0975 \%$ \\
Daily Volatility & $1.4566 \%$ & $3.1219 \%$ \\
\hline \hline
\end{tabular}

\section{Concluding Remarks}

The unofficial dollarization is motivated gradually and adopted voluntarily by the people due to the consistent local currency devaluation, the absence of effective central bank with the ability to determine the amount of banknotes in the economy and the highly fragile floating exchange rate regime.

The study adopted daily exchange rate data of Somali Shilling to US dollars for 10 years period and applied time series analysis to determine the effect of the exchange rate and its role to motivate local currency devaluation and the unofficial dollarization. The empirical evidence in this paper concludes that the exchange rate regime is not significant factor of unofficial dollarization; the volatility of exchange rate is not very much persistent in the study period. Considering that fluctuations of the exchange rate is not as significant as its thought to have important effect on the unofficial dollarization in Somalia during 2009-2018. Analyzing the other factors that may cause the spread of unofficial dollarization and the local currency devaluation in Somalia would be helpful in the attempt to reduce the challenges faced by the country's economic stability.

The Central Bank of Somalia should monitor the overall macroeconomic issues of the country by employing the appropriate monetary policies, controlling the issue of banknotes by other domestic authorities or private entities and restore the public confidence on the domestic currency to use it back as a means of exchange and store of value. 


\section{REFERENCES}

African Development Bank (2019), “African Economic Outlook 2019” [online]. Publications 14 March 2019-175 Tunis. Available from https://www.afdb.org /en/knowledge/publications/african-economic-outlook/

Alesina, Alberto and Robert J. Barro (2001), "Dollarization." American Economic Review, 91(2), 381-385.

Balino, T., Bennet, A. and Borensztein, E. (1999), "Monetary Policy in Dollarized Economies" $\begin{array}{lllll}\text { [online]. } & \text { Occasional } & \text { Paper } & \text { Available } & \text { from }\end{array}$ https://www.imf.org/external/pubs/nft/op/171/

Bogetic, Zeljko (2000), "Official Dollarization: Current Experiences and Issues", Cato Journal, 20(2), 179-213.

Bollerslev, Tim (1986), "Generalized Autoregressive Conditional Heteroskedasticity", Journal of Econometrics, 31(3), 307-327.

Business dictionary (2019), "Definition of Dollarization" [online]. Available from http://www.businessdictionary.com/definition/dollarization.html [Accessed 16.5. 2019].

Calvo, G. A. (2002), "On Dollarization" Economics of Transition, 10(2), 393-403.

Chiţu, Livia (2012), "Was Unofficial Dollarization/Euroization An Amplifier of the "Great Recession” of 2007-2009 In Emerging Economies?” Working Paper Series No 1473 Frankfurt. Available from https://www.ecb.europa.eu/pub/pdf/scpwps/ecbwp1473.pdf

Chossudovsky, Michel. (2011), "Somalia: the Real Causes of Famine" [online]. , Available from https://www.globalresearch.ca/somalia-the-real-causes-of-famine/25725 [Accessed 21.2. 2019].

Duffy, J., Nikitin, M., Smith R. Todd (2004), "Dollarization Traps", Journal of Money, Credit, and Banking, 38(8), 1-34.

Eichengreen, B. (2002), "When to Dollarize", Journal of Money, Credit, and Banking, 34(1), $1-24$. 
Engle, Robert F. (1982), "Autoregressive Conditional Heteroscedasticity with Estimates of the Variance of United Kingdom Inflation" Econometrica, Econometric Society, 50(4), 987-1007.

Honig, Adam. (2009), "Dollarization, Exchange Rate Regimes and Government Quality", Journal of International Money and Finance, 28(2)198-214.

Kang, Kiwon (2005), "Is Dollarization Good for Cambodia?", Global Economic Review, 34(2), 201-211.

Koshin, Muktar Adan A. (2017), "Overcoming Challenges in an Unrecognized Economy: Experience from Somaliland", American International Journal of Contemporary Research, 7(1) 79-86.

Lakić S., Šehović D. and Ćetković J. (2016), “An analysis of the offi cial dollarization regime in Montenegro: theoretical approaches and empirical evidence", Journal of International Studies, 9(2), 48-64.

Marcia Towers, \& Borzutzky, S. (2004), "The Socioeconomic Implications of Dollarization in El Salvador", Latin American Politics and Society, 46(3), 29-54.

Matthews, David A; Balasundram Maniam; Leavell, Hadley; Burke, Claudine (2006),"The Case of Ecuador's Dollarization", Journal of Economics and Economic Education Research, 7(3) 87-101.

Mengesha, Lula G. \& Holmes, Mark J. (2015), "Does dollarization reduce or produce inflation?", Journal of Economic Studies, 42(3), 358-376.

Musse, Osman Sayid Hassan and Echchabi, Abdelghani (2017), "Dollarization in East Africa: Causes, Consequences and Future Forecasts", Binus Business Review, 8(1), 15-22.

Musoke, Zakia (2017), "An empirical investigation on dollarization and currency devaluation: A case study of Tanzania", Economics Discussion Papers, Kiel Institute for the World Economy, 1-17.

Nor, M. Ibrahim. (2012), "The Effect of Dollarization on Developing Economies: Lessons From Somalia's Informal Market" Academic Research International, 2. 591-597. 